\title{
Research and Optimization of the Belt Truss Location in High-Rise RCC Structure
}

\author{
Shravan Vijay Mantri, P. Hiwase, Prasad P. Dahale
}

\begin{abstract}
Rapid improvement in infrastructure to acquire the development of modern civilization is the demand of high-rise structures. As day by day, the height of structures is increasing there is problem with its stiffness which induces lateral stability and sway due to lateral forces, which has to be reduce. One more structural system has been developed to overcome problems related to lateral stability and sway of building. To reduce the lateral deflection due to earthquake or wind forces, one of the most efficient and economical structural system used to knock out these challenges is the use of belt truss and outrigger truss. It is commonly used to control the excessive drift due to lateral load, so that during minor or major earthquake, the risk of structural and non-structural damage can reduce to sufficient amount. The objective of this thesis is to optimize the location of belt truss to control the deflection or sway of building. Here, Belt truss can be shear wall, hollow steel sections, braced sections and many more. In this paper, we are going to compare the results due to different locations of shear wall and X-braced section. Structure is located in earthquake zone IV(India) on Hard rock strata. Different results to be compared are Lateral Deflection, story drift. Study provides comparison between the two, by analyzing and designing the $G+24$ irregular residential structure. By using belt truss at ideal location, overall lateral deflection reduces by $22 \%$. And this ideal location is obtained when the belt truss is applied at $13^{\text {th }} \& 14^{\text {th }}$ floors simultaneously. From this location of belt truss, we can conclude that the lateral deflection of the high-rise structure can be reduce by applying the belt truss in the middle floors.
\end{abstract}

Key words - Belt truss, Lateral deflection, Storey drift, Highrise structures.

\section{INTRODUCTION}

Growth in structural system and high strength material creating influence on rapid development of tall buildings and it is also need of growing population and infrastructures in metro cities. The development in concrete technology over the twenty-first century covering structural system, analysis, construction techniques and materials, made it possible to build tall structure. There are many design objectives for structural engineers to control the design of high-rise buildings such as safety, serviceability, durability, functionality, economic effectiveness, structural integrity and resistance to accidental actions. But, the main factors that will undermine the design are the building drift due to lateral loads and prevention of progressive collapse attributed to the accidental loads resulting in column loss. When the lateral load acts on the building, the bending of

Revised Manuscript Received on July 10, 2019.

Shravan Vijay Mantri, M. Tech (Structural Engineering), Department of Civil Engineering, Shri Ramdeobaba college of Engineering and Management, Nagpur, Maharashtra, India (shravanm74@gmail.com)

Dr. Prashant P. Hiwase, Assistant Professor, Department of Civil Engineering, Shri Ramdeobaba college of Engineering and Management, Nagpur, Maharashtra, India (prashant.hiwase@ gmail.com)

Dr. Prasad P. Dahale, Associate Professor, Department of Civil Engineering, Shri Ramdeobaba college of Engineering and Management, Nagpur, Maharashtra, India. (dahale.prasad@ rediffmail.com) the core revolves the outrigger arm, which is connected to the core of structure and brings compression and tension on columns.

\section{Structural system for multi-storied storied buildings:}

There are two categories of structural system i.e. interior structures and exterior structures. When the major part of lateral load resisting structure is located in inner part of the building it is called interior structure and if major part of the lateral load resisting system is located on perimeter of building is called as exterior structure. One of the most effective techniques to reduce the lateral drift, that are likely applied in the design of high rise structure is the use of outrigger truss and belt truss. Interior structure consists of belt truss, while exterior structure is for outrigger truss. Advantage of core-outrigger truss are that spacing of exterior column spacing can easily meet functional and aesthetic requirements and the building's exterior framing can meet simple beam-column framing without any rigid frame connections. But there are some problems with outrigger truss that are:

a) area occupied by truss mainly diagonal can create a floor to floor spacing problem

b) architectural aspect

c) connection to core, especially when shear walls are used.

To overcome this problem belt truss as a virtual outrigger truss is used, as it is connected on periphery of structure.

\section{Objective and details of present study}

The main objective of present study is to study the use belt truss as a virtual outrigger truss placed at different location, to control the deflection of multi-storied building against lateral loads acting through seismic load and wind load. The study is restricted to reinforced cement concrete multi-storied structure. The analyzed model in study is real structure 

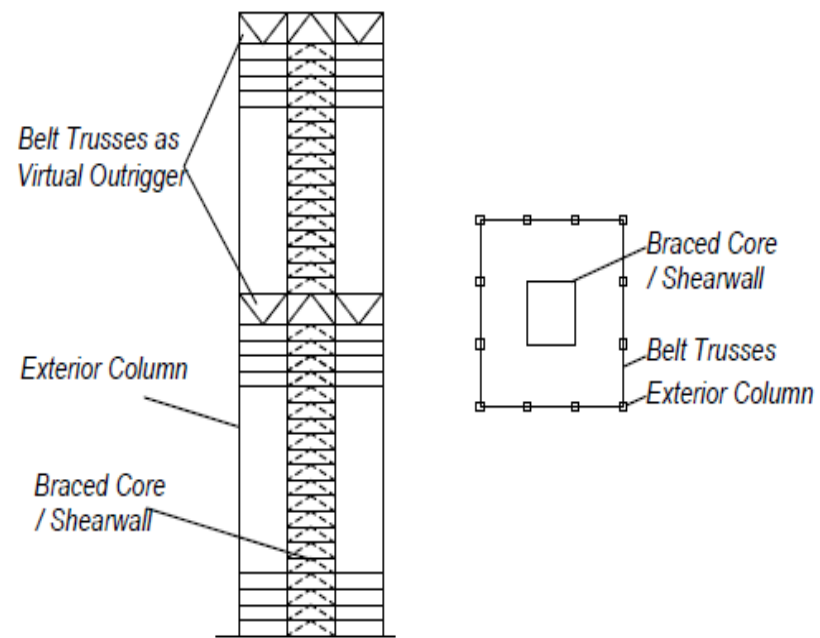

Fig.1 Outrigger and belt truss

implementing in Mumbai with 24 stories. Dimension of plan along $\mathrm{X}, \mathrm{Y}$ axis is $33.810 \mathrm{~m} \& 21.4 \mathrm{~m}$ while elevation of building is $80.2 \mathrm{~m}$ excluding foundation. The shape of building is irregular structure. Plan and 3D model of building is shown in fig $2 \&$ fig 3 .

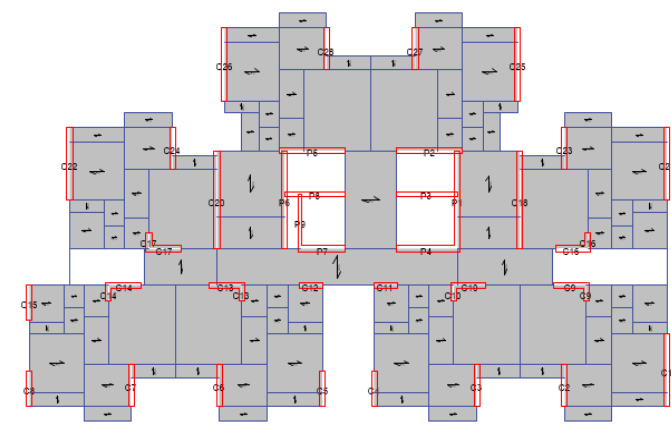

Fig.2. Plan of building at $13^{\text {th }}$ floor

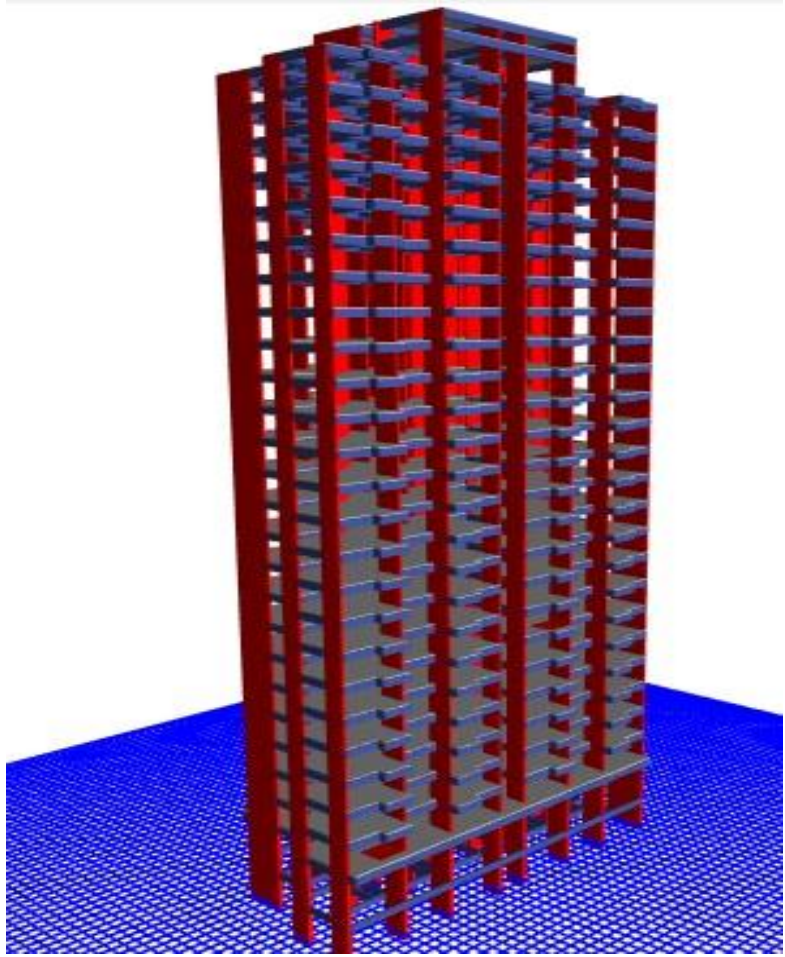

Fig.3. 3D model of structure

Structural data

\begin{tabular}{ll} 
Plan dimension & $33.810 \mathrm{~m}, 21.4 \mathrm{~m}$ \\
\hline Total height of building & $80.2 \mathrm{~m}$ \\
Height of each storey & $2.9 \mathrm{~m}$ \\
Height of parapet & $1 \mathrm{~m}$ \\
Grade of concrete & $\mathrm{M} 35, \mathrm{M} 40$ \\
Density of concrete & $25 \mathrm{KN} / \mathrm{m}^{3}$ \\
Grade of steel & Fe 500 \\
Type of Beam & Size of Beams \\
B1 & $150 \mathrm{mmX} 300 \mathrm{~mm}$ \\
B2 & $150 \mathrm{mmX} 600 \mathrm{~mm}$ \\
B3 & $150 \mathrm{mmX} 700 \mathrm{~mm}$ \\
B4 & $230 \mathrm{mmX} 600 \mathrm{~mm}$ \\
B5 & $230 \mathrm{mmX} 700 \mathrm{~mm}$ \\
Thickness of Shear Wall & $150 \mathrm{~mm}, 230 \mathrm{~mm}$ \\
& $380 \mathrm{~mm}, 430 \mathrm{~mm}$ \\
Thickness of Slab & $125 \mathrm{~mm}, 140 \mathrm{~mm}$ \\
Thickness of Wall & $150 \mathrm{~mm}-$ internal wall \\
& $230 \mathrm{~mm}-$ external wall \\
Seismic Zone & IV \\
Wind Speed & $44 \mathrm{~m} / \mathrm{s}$ \\
Soil Condition & Medium soil \\
Importance factor & 1 \\
Zone factor & 0.24 \\
Terrain category & 3 \\
Damping ratio & $5 \%$ \\
Loadings- & \\
Dead load: & \\
$\quad$ a. Terrace floor finish & $3.5 \mathrm{KN} / \mathrm{m}^{2}$ \\
$\quad$ b. Toilet floor finish & $1.5 \mathrm{KN} / \mathrm{m}^{2}$ \\
$\quad$ d. Sunk load floor finish $\quad$ Passages floor finish & $3.7 \mathrm{KN} / \mathrm{m}^{2}$ \\
& $1.5 \mathrm{KN} / \mathrm{m}^{2}$ \\
\hline
\end{tabular}




\begin{tabular}{|cll|}
\hline e. & Stair case floor finish & $1.5 \mathrm{KN} / \mathrm{m}^{2}$ \\
f. & Balconies floor finish & $1.5 \mathrm{KN} / \mathrm{m}^{2}$ \\
g. & Floor finish & $1.5 \mathrm{KN} / \mathrm{m}^{2}$ \\
h. $125 \mathrm{~mm}$ slab & $3.125 \mathrm{KN} / \mathrm{m}^{2}$ \\
i. $140 \mathrm{~mm}$ slab & $3.5 \mathrm{KN} / \mathrm{m}^{2}$ \\
j. $\quad$ External wall & $3.8 \mathrm{KN} / \mathrm{m}^{2}$ \\
k. Internal wall & $2.48 \mathrm{KN} / \mathrm{m}$ \\
Live load: & \\
a. Terrace & $2 \mathrm{KN} / \mathrm{m}^{2}$ \\
b. Toilet & $2 \mathrm{KN} / \mathrm{m}^{2}$ \\
c. Passages & $3 \mathrm{KN} / \mathrm{m}^{2}$ \\
d. Stair case & $4 \mathrm{KN} / \mathrm{m}^{2}$ \\
e. $\quad$ Balconies & $2 \mathrm{KN} / \mathrm{m}^{2}$ \\
f. Lift machine & $20 \mathrm{KN} / \mathrm{m}^{2}$ \\
g. & Water tank & $10 \mathrm{KN} / \mathrm{m}^{2}$ \\
h. & 125 mm slab & $2 \mathrm{KN} / \mathrm{m}^{2}$ \\
i. & 140 mm slab & $2 \mathrm{KN} / \mathrm{m}^{2}$ \\
j. & Refuge floor & $4 \mathrm{KN} / \mathrm{m}^{2}$ \\
\hline
\end{tabular}

\section{ANALYSIS}

The building is a R.C.C shear walls and beam slab frame structure. After preliminary sizing of various structural members, a computer model of the structural frame of the building will be generated for carrying out computer analysis for the effects of vertical and lateral load that are likely to be imposed on the structure. The building structure will be analyzed using the ETABS.15.2.0 software. For the design of R.C.C. elements, the Limit State Method will be used as per IS 456-2000. Materials of construction will be predominantly concrete with consideration for strength and durability. The minimum grade of concrete is suggested as M: 30. High Yield Strength Deformed bars conforming to $\mathrm{Fy}=500 \mathrm{MPa}$. Covers to reinforcement shall be in accordance with IS: 456:2000. Geometrical dimensions, member properties and member node connectivity including eccentricities will be modeled in the analysis problem. Variation in material grades, if present, will also be considered. The seismic loads will be derived from the results of dynamic analysis of the structure in accordance with the relevant code of practice. The permissible values of the load factors and stresses will be utilized within the purview of the Indian Standards.

The computer analysis will evaluate individual internal member forces, reactions at foundation level and deflection pattern of the entire structure and in the individual members. This data will then be used to verify adequacy of the member sizes adopted and after further iterations arrive at the most appropriate design of the structural members. Some re-runs of the analysis program might be required for arriving at the optimum structural space frame characteristics that satisfy the strength and stability criteria in all respects.

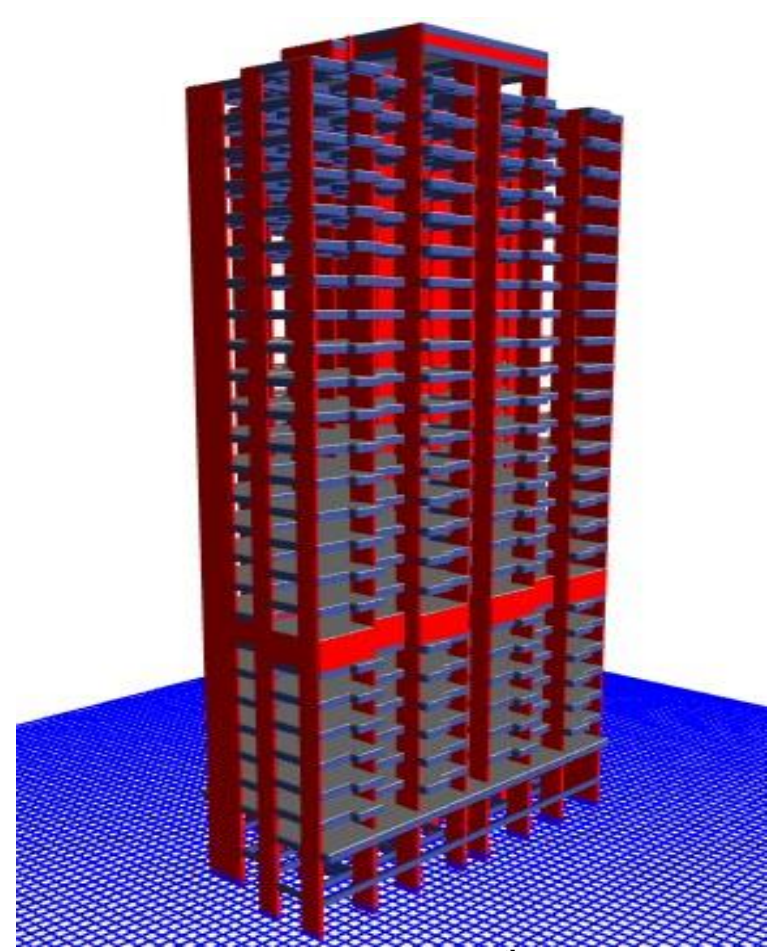

Fig. 4. Shear wall at $8^{\text {th }}$ floor

Space frame analysis will be carried out for gravity loads, wind loads and seismic loads.

In the present study total 17 models are studied are:

\begin{tabular}{|c|c|c|c|c|c|}
\hline Sr. & Structure & $\begin{array}{c}\text { R. S. } \\
\text { in X } \\
\text { No. }\end{array}$ & $\begin{array}{c}\text { R. S. } \\
\text { in Y } \\
(\mathrm{mm})\end{array}$ & $\begin{array}{c}\text { Wind } \\
\text { in X } \\
(\mathrm{mm})\end{array}$ & $\begin{array}{c}\text { Wind } \\
\text { In Y } \\
(\mathrm{mm})\end{array}$ \\
\hline 1. & $\begin{array}{c}\text { Without belt } \\
\text { truss }\end{array}$ & 44 & 39.8 & 52.95 & $\begin{array}{c}104.6 \\
7\end{array}$ \\
\hline
\end{tabular}

\section{WITH BELT TRUSS AS SHEAR WALL}

\begin{tabular}{|c|c|c|c|c|c|}
\hline 2. & At $8^{\text {th }}$ floor & 37.44 & 32.9 & 45.65 & 96.73 \\
\hline 3. & At $12^{\text {th }}$ floor & 36.6 & 31.6 & 44.32 & 94 \\
\hline 4. & $\begin{array}{l}\text { At } 8^{\text {th }} \text { and } \\
16^{\text {th }} \text { floor }\end{array}$ & 35.89 & 30.4 & 43.87 & 91.56 \\
\hline 5. & $\begin{array}{l}\text { At } 12^{\text {th }} \text { and } \\
\text { terrace floor }\end{array}$ & 35.3 & 31.53 & 43.02 & 94.15 \\
\hline & \multicolumn{5}{|c|}{ Simultaneously at two floors } \\
\hline 6. & $\begin{array}{l}\text { At } 8^{\text {th }} \text { and } 9^{\text {th }} \\
\text { floor }\end{array}$ & 34.26 & 32.05 & 42.13 & 95.38 \\
\hline 7. & $\begin{array}{l}\text { At } 13^{\text {th }} \text { and } \\
14^{\text {th }} \text { floor }\end{array}$ & 36.3 & 31.92 & 41.29 & 95.75 \\
\hline 8. & $\begin{array}{l}\text { At } 8,9^{\text {th }} \text { and } \\
16,17^{\text {th }} \text { floor }\end{array}$ & 32.76 & 26.02 & 40.89 & 87.63 \\
\hline 9. & $\begin{array}{l}\text { At } 12,13^{\text {th }} \\
\text { and } 24, \\
\text { terrace floor }\end{array}$ & 30.87 & 29.85 & 38.73 & 89.23 \\
\hline \multicolumn{6}{|c|}{ WITH BELT TRUSS AS X-BRACE } \\
\hline 10. & At $8^{\text {th }}$ floor & 38.15 & 34.62 & 46.18 & 97.98 \\
\hline 11. & At $12^{\text {th }}$ floor & 37.9 & 33.62 & 45.69 & 96.32 \\
\hline 12. & $\begin{array}{l}\text { At } 8^{\text {th }} \text { and } \\
16^{\text {th }} \text { floor }\end{array}$ & 30.2 & 29.3 & 39.16 & 90.15 \\
\hline
\end{tabular}




\begin{tabular}{|c|c|c|c|c|c|}
\hline 13. & $\begin{array}{c}\text { At } 12^{\text {th }} \text { and } \\
\text { terrace floor }\end{array}$ & 31.1 & 30.15 & 41.12 & 91.23 \\
\hline 14. & \begin{tabular}{|} 
Simultaneously at two floors \\
At $8^{\text {th }}$ and $9^{\text {th }}$ \\
floor
\end{tabular} & 34.82 & 32.7 & 42.63 & 96.01 \\
\hline 15. & $\begin{array}{c}\text { At } 12^{\text {th }} \text { and } \\
13^{\text {th }} \text { floor } \\
16 .\end{array}$ & 34.24 & 32.9 & 42.48 & 95.76 \\
\hline $\begin{array}{c}\text { At } 8,9^{\text {th }} \text { and } \\
16,17^{\text {th }} \text { floor } \\
\text { At } 12,13^{\text {th }} \\
\text { and 24, } \\
\text { terrace floor }\end{array}$ & 29.32 & 27.45 & 38.32 & 89 \\
\hline 17. & 30.85 & 40.78 & 91.56 \\
\hline
\end{tabular}

Figure 4 shows shear wall at $8^{\text {th }}$ floor and figure 5 shows $\mathrm{X}$-brace at $8^{\text {th }}$ floor.

\section{LOAD COMBINATION}

The results obtained from the computer analysis in the form of member forces and reactions will be used for design the structural members. Following load combinations of the member forces will be considered for arriving at the design forces.

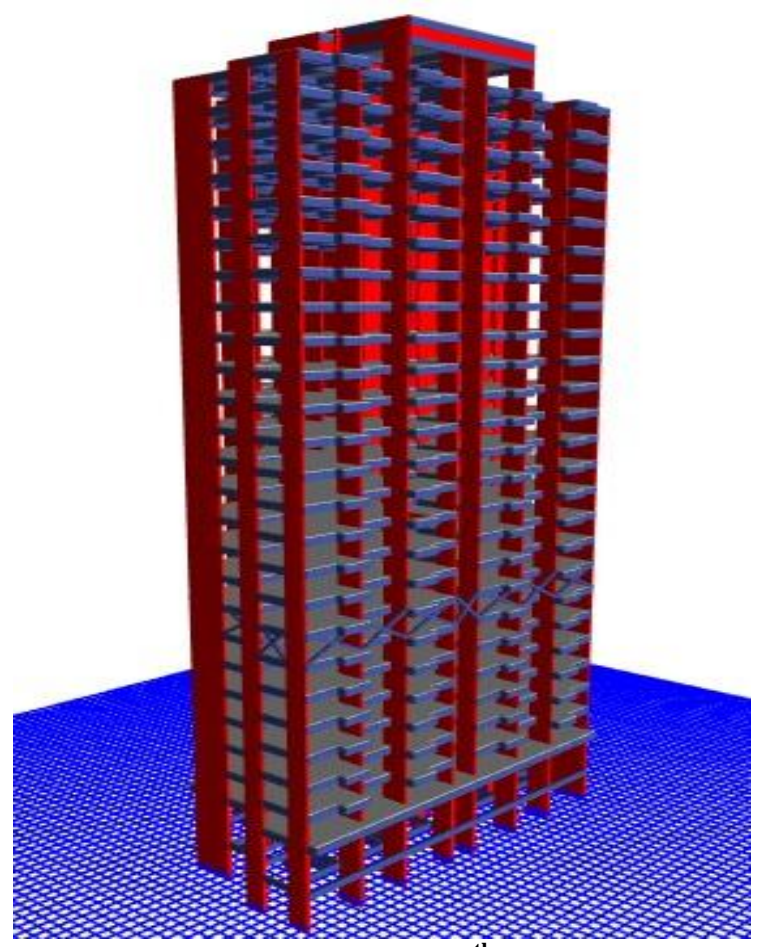

Fig. 5. X-brace at $8^{\text {th }}$ floor

Load combinations:

1.5 Dead + 1.5 Live

$1.5 \mathrm{Dead} \pm 1.5 \mathrm{Wx} / \mathrm{Wy} / \mathrm{EQx} / \mathrm{EQy}$

1.2 Dead + 1.2 Live $\pm 1.2 \mathrm{Wx} / \mathrm{Wy} / \mathrm{EQx} / \mathrm{EQy}$

0.9 Dead $\pm 1.5 \mathrm{Wx} / \mathrm{Wy} / \mathrm{EQx} / \mathrm{EQy}$

Suffixes $\mathrm{x}$ and $\mathrm{y}$ in the above table indicate the direction in which the force is applied.

All members will be designed for the largest value of the design forces obtained due to positive as well as negative values of reversible forces (Wind and Earthquake).

\section{RESULT AND DISCUSSION}

In present study the different parametric studied are lateral storey displacements and storey drift using ETABS.
Followings graphs represents values without belt truss, with belt truss as shear wall and $\mathrm{x}$-bracing.

\section{A. Lateral Displacement:}

From the figures 6 and 7 it is observed that lateral displacement for response specturm method is reduced by $21 \%$ in $\mathrm{X}$ direction and $18 \%$ in $\mathrm{Y}$ direction,by applying shear and $\mathrm{X}$ bracing as belt truss system.

From the figures 8 and 9 it is observed that lateral displacement for wind analysis is reduced by $16 \%$ in $\mathrm{X}$ direction and $23 \%$ in $\mathrm{Y}$ direction,by applying shear and $\mathrm{X}$ bracing as belt truss system.

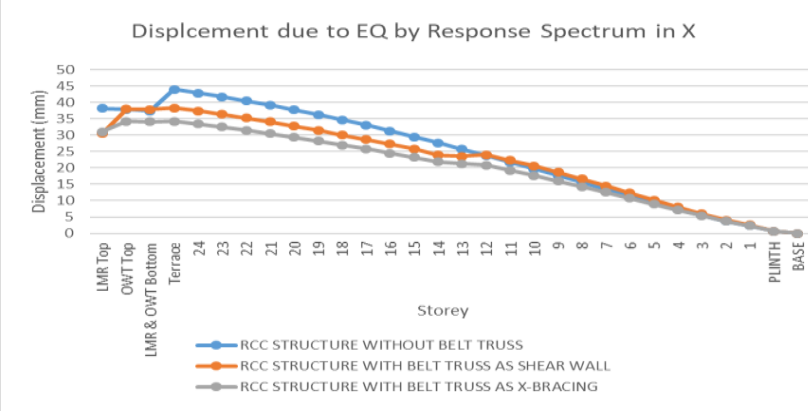

Fig.6. Lateral displacement for Response spectrum in Xdirection

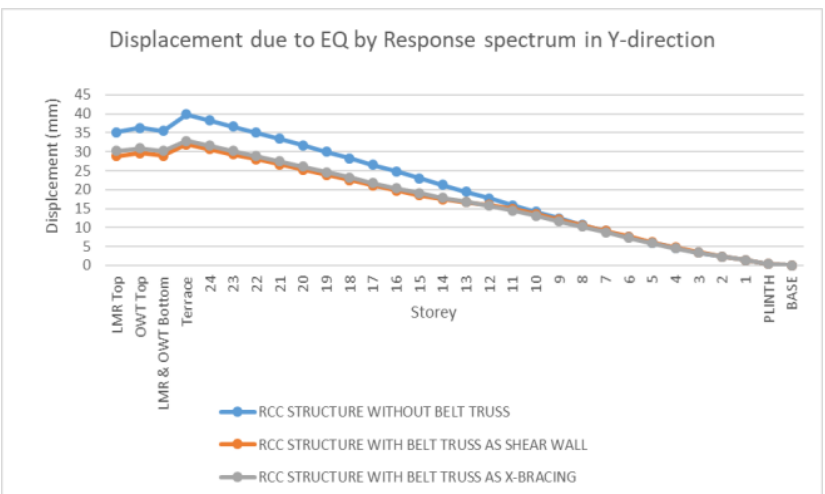

Fig.7. Lateral displacement for response spectrum in $\mathrm{Y}$ direction.

\section{B. Storey drift:}

By applying shear and $\mathrm{X}$ bracing as belt truss system, it is observed that drift for response specturm method is reduced by $48 \%$ in $\mathrm{X}$ direction and $42 \%$ in Y direction for partocular floor's as shown in figures 10 and 11 .

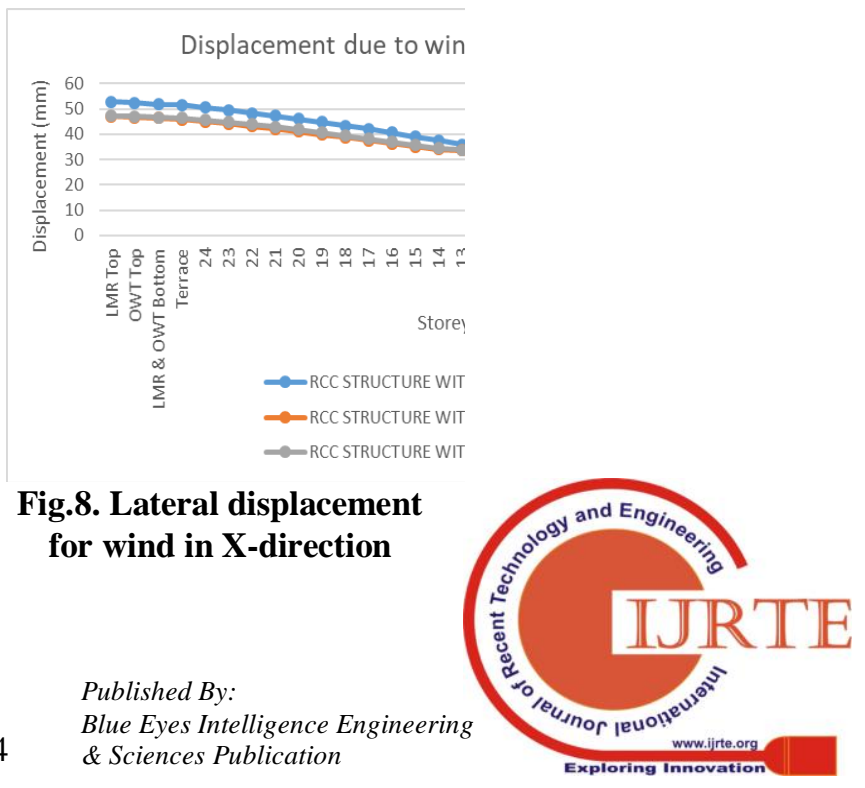




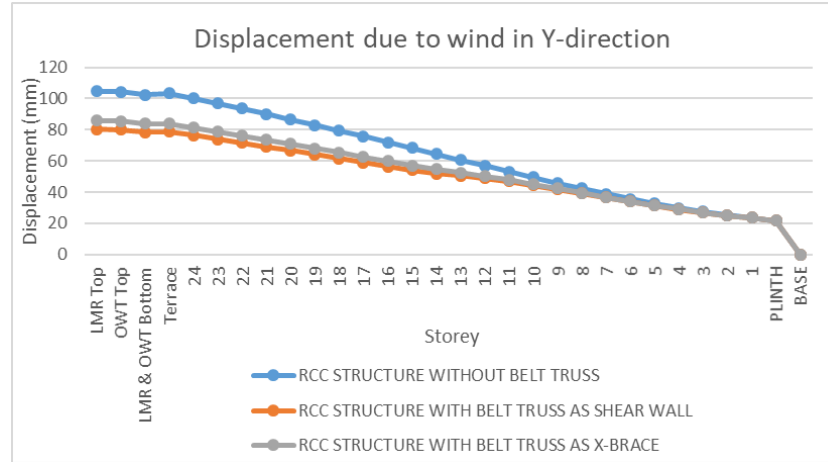

Fig.9. Lateral displacement for wind in Y-direction

By applying shear and $\mathrm{X}$ bracing as belt truss system, it is observed that drift for wind analysis is reduced by $44 \%$ in $\mathrm{X}$ direction and $49 \%$ in $\mathrm{Y}$ direction for particular floor's as shown in figures 12 and 13.

Drift due to EQ by Response Spectrum in X-direction

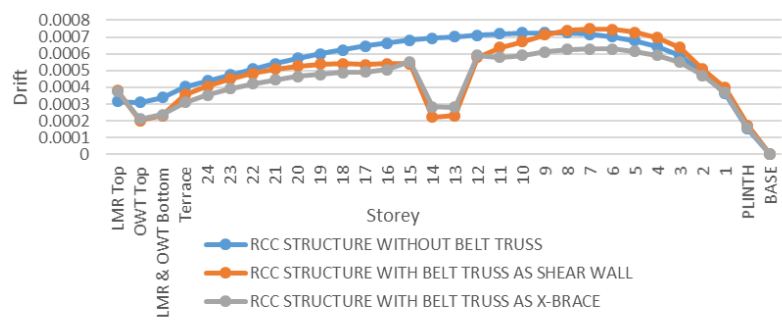

Fig.10. Drift for Response spectrum in X-direction

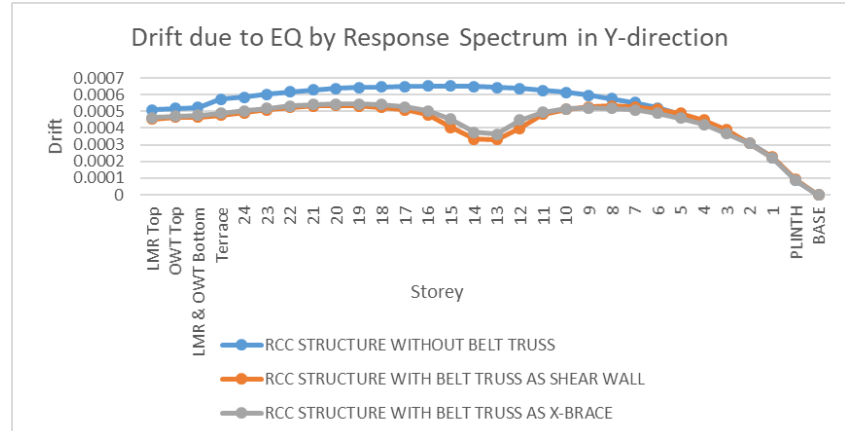

Fig.11. Drift for response spectrum in Y-direction

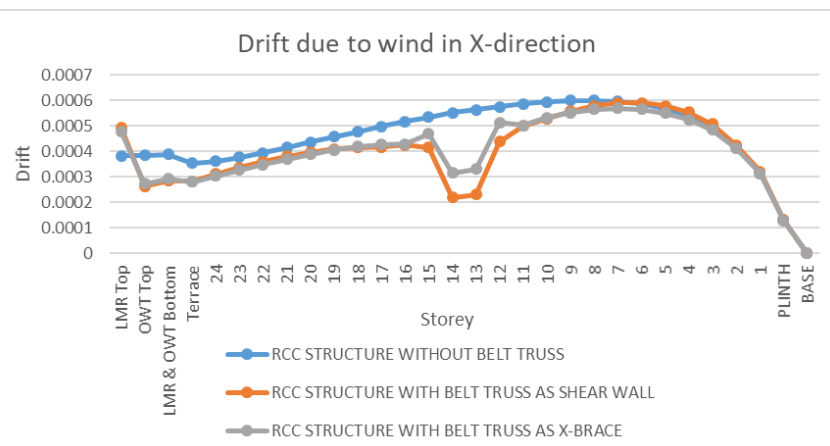

Fig.12. Drift for wind in X-direction

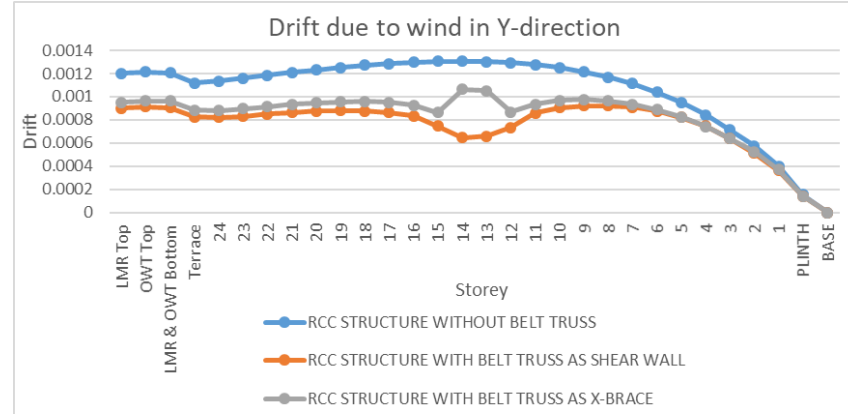

Fig.13. Drift for wind in Y-direction

\section{CONCLUSION}

Here, different techniques were proposed for the application of belt truss as an outrigger. As the results were discussed, in the previous section, for G+24 building by applying belt truss at different locations. Thus from the discussion of above observations and results, we come to the following concluding statements as:

1. The use of belt truss structural systems in high-rise buildings increases the stiffness and makes the structural form efficient under lateral load.

2. Results were found to be more less at different location, but the optimum location was observed at $13^{\text {th }}$ and $14^{\text {th }}$ floor.

3. Lateral deflection was reduced by $21 \%$ and $18 \%$ in Response spectrum method, while in wind it was reduced by $16 \%$ and $23 \%$ in $\mathrm{X}$ and $\mathrm{Y}$ direction.

4. Drift at particular floor was reduced by $48 \%$ and $42 \%$ in Response spectrum method, while in wind it was reduced by $44 \%$ and $49 \%$ in $\mathrm{X}$ and $\mathrm{Y}$ direction.

5. Provision of belt truss results in well distribution of design reaction and axial force in perimeter column that will help in column design to maintain same size of column and help to reduce column sizes.

\section{REFERENCES}

1. S. Chen, B. Mulgrew, and P. M. Grant, "A clustering technique for digital communications channel equalization using radial basis function networks," IEEE Trans. on Neural Networks, vol. 4, pp. 570-578, July 1993.

2. J. U. Duncombe, "Infrared navigation-Part I: An assessment of feasibility," IEEE Trans. Electron Devices, vol. ED-11, pp. 34-39, Jan. 1959.

3. C. Y. Lin, M. Wu, J. A. Bloom, I. J. Cox, and M. Miller, "Rotation, scale, and translation resilient public watermarking for images," IEEE Trans. Image Process., vol. 10, no. 5, pp. 767-782, May 2001.

4. Nair, R. S., Belt Trusses and Basements as „Virtuale Outriggers for Tall Buildings, Engineering Journal, AISC, Fourth Quarter/1998, pp. 140-146.

5. Z. Bayati1, m. Mahdikhani and A. Rahaei, Optimized Use of Multi-Outriggers System to Stiffen Tall Buildings, the $14^{\text {th }}$ world conference on earthquake engineering, October 12-17, 2008, Beijing, China.

6. M. R. Jahanshahi, R. Rahgozar, Optimum Location of Outrigger-belt Truss in Tall Buildings Based on Maximization of the Belt Truss Strain Energy, International Journal of Engineering, Vol. 26, No. 7, (July 2013), pp. 693-700.

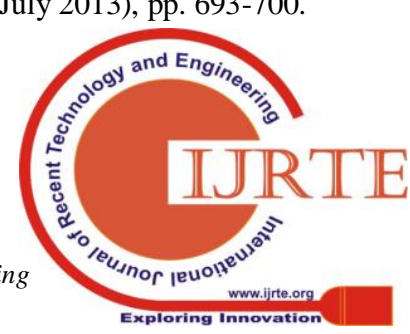


7. M. R. Jahanshahi, R. Rahgozar a, M. Malekinejad, A Simple Approach to Static Analysis of Tall Buildings with a Combined Tube-intube and Outrigger-belt Truss System Subjected to Lateral Loading, International Journal of Engineering, Vol. 25, No. 3, (July 2012), pp. 289-299.

8. Bhavesh R. Sahni, Prashant D. Hiwase, and Prasad P. Dahale ,"Seismic behaviour of flat slab building with shear wall according to IS 1893 2016" International Journal of Civil Engineering and Technology (IJCIET), Volume 9, Issue 5, May 2018, Pages 955-963 Publisher IAEME Publication.

9. Prashant D. Hiwase, Anuj Shiwal, Meet Bhagat, Aditya Tripathi, Shreya Umredkar "Seismic analysis of hostel building under various earthquakes zones in India", International organization of Scientific Research (IOSR) Journal of Engineering, ISSN(Online) : 2250-3021, ISSN(Print) : 2278-8719, IOSRJEN : SPECIAL ISSUE, Volume 7, May 2019, Pages 38-42

10. Prashant D. Hiwase, Sakshi Waths, Nandini Dange, Shraddha Malve, Tanmay Bhansali "Comparison of seismic analysis and static analysis of residential building using staad.pro", International organization of Scientific Research (IOSR) Journal of Engineering, ISSN(Online) : 2250-3021, ISSN(Print) : 2278-8719, IOSRJEN : SPECIAL ISSUE, Volume 7, May 2019, Pages 27-30

11. IS: 456-2000. Plain and Reinforced Concrete- Code of Practice (Fourth Revision), Bureau of Indian Standard, New Delhi. IS: 1893(Part-I)-2002, Criteria for Earthquake Resistant Design of Structures, Bureau of Indian Standard, New Delhi.

12. IS 875 (part-3) - 1987. "Code of practice for design loads (other than earthquake) for building and structures, wind load". Bureau of Indian Standard, New Delhi. 